Journal of Social Sciences 5(1): 67-75, 2009

ISSN 1549-3652

(C) 2009 Science Publications

\title{
Jordanian Women and Education
}

\author{
Bashar Al-Saleem, Nidal Al-Ahmad, Yousra Al-Ali and Mohammed Al-Dibs \\ Department of Educational Sciences, Faculty of Prince Alia, \\ Al-Balqa Applied University, Alshmesani, Amman, Jordan
}

\begin{abstract}
Problem statement: Women in Jordan and Arab world in general and in the world received basic secondary education and entered the realm of secondary and university education, this development has taken time, effort and struggle. Approach: To Give historical background of the development of women's education in Jordan, analyze the legal legislation related to the education of Jordanian women, analyze the Jordanian educational efforts for the development of women. Summarize the most important prerequisites for increasing the effectiveness of the women's role in the educational process within the Jordanian society efforts in the development of women from the perspective that women constitute half of society and in line with humanitarian, civilized and global propounding related to women's affairs and to address issues related to learning, a prelude to enable them to take its course in all fields and levels. Results: The educational system in Jordan focused its attention on women seeking to make a quantitative and qualitative aspects quantum leap that matches or even surpasses the development that had taken place for male education. Conclusion/Recommendations: The study highlights the importance and the need to increase the effectiveness of the role of women in Jordanian society through a number of proposals including, support women requesting and working towards self-development to meet the challenges and difficulties impeding progress in different educational institutions.
\end{abstract}

Key words: woman, education, Jordan

\section{INTRODUCTION}

The march of women's education through the last five decades reflects the keen interest by the Hashemite leadership in the provision of educational opportunities and achieving Parity for all, regardless of gender, language or religion, in various parts of the Kingdom: Cities, rural areas and the desert badia.

The Jordanian society has witnessed major and remarkable development in all of economic, Social and political fields. One of the most important forms of this development that touched on the role of women, contributing effectively to the achievement of economic and social development through its participation in all aspects of public life, education, employment and politics enabled her to work side by side with men in building this precious homeland.

Female education in Jordan have been considered at the end of the nineteenth century and early twentieth century as unnecessary, a threat and inappropriate, while male students continued to high school level, their sister girls were forced to stay at home. The areas of education that were presented to them did not exceed household chores and tasks usually required as future wives and mothers. Females in earlier periods did not have equality with men at the level of education, but the attention was subsequently drawn to the importance of female education whereby this issue took a civilized human dimension and this attention gradually began to invest in female energies increasingly. However women's access to knowledge whether available or even extracted did not stop at this point, since there are still battles to be won, especially jobs given only to men, considered a monopoly and to the challenge and self demonstration in the community that they belong to $^{[1]}$.

Because of the Hashemite leadership's keen belief of the need to provide educational opportunities for Jordanians, this trend has been embodied with the educational legislation of different levels starting with the constitution and its passing laws that dealt with the educational matters and related regulations, instructions and applied basics.

The multiplicity and diversity of educational opportunities spread in different parts of the Kingdom for both sexes lead to the rise in female enrollment ratio

Corresponding Author: Bashar Al-Saleem, Department of Educational Sciences, Faculty of Prince Alia, Al-Balqa Applied University, Alshmesani, Amman, Jordan Tel: +962 777215263 
of the various stages of education levels at a degree that exceeded males. Furthermore the existing gap in literacy rates (alphabet) between males and females due to the efforts made in the area of literacy in its preventive and curative aspects. Jordan has scored the highest percentage among Arab countries in general and with girls' education in particular. It is worth noting that Jordan ranks (93) among (174) countries in the area of developing countries according to the United Nations Human Development report for the year $2000^{[2]}$. But this tangible progress in the enrollment of women in education at all levels and forms, has not been matched by a similar progress in changing women's contribution and active involvement in economic development and entry of the labor market on one hand and effective political participation and decision-making levels all on the other hand. This calls for the need to move in future policies to enable and qualify for the empowerment of women, her rehabilitation, especially in the field of information and communication technologies and appropriate skills to the era of know-how economy, leading the way for better integration in the economic and Political development in its varied dimensions through a comprehensive plan implemented in coordination with various public and private sectors.

\section{MATERIALS AND METHODS}

The objectives of the study are summarized in the following points:

- Providing historical background to the development of women's education in Jordan

- Illustrating the legislation relating to the education of women

- Illustrating the Jordanian educational efforts for the development of women

- Illustrating the basic requirements for increasing the effectiveness of the role of the women in the educational process within the Jordanian society
Stages of the study: In the view of the study problems, its importance and its objectives, it runs according to the following stages:

- The historical background of the development of women's education in Jordan

- Jordanian women's education and legislation

- Jordanian women and the educational efforts of their development

- The most important prerequisites for increasing the effectiveness of women's role in the educational process within the Jordanian society

\section{RESULTS}

Historical background of the development of women's education in Jordan: Below is a demonstration and a brief analysis of the most important information obtained regarding the quantitative and qualitative dimension for the development of Jordanian women:

- Quantitative development for the education of females in Jordan

Table 1 Demonstrates that the number of schools in Jordan rose from (958) in the school year (1952/53) to (5366) in the school year $(2004 / 05)^{[3]}$. As shown in Table 1 the total number of students enrolled in schools in Jordan in the year (1952/53), were (170777) students; the female students numbered (45973) representing a rate of $(26.92 \%)$ of the total students. Table 1 shows that the number of female workers in the teaching profession has risen from (1403) teachers for the year $(1952 / 53$ The number of students during the past five decades, has doubled several times to reach (1522700) students for the year (2004/2005). The number of female students reached (745444) representing a percentage of $(48.95 \%)$ of the total number of students for that year; in other words, with regard to the development of teacher preparation),

Table 1: Development of the No. of schools, students and teachers in Jordan during the period (1952-2005) according to gender

\begin{tabular}{|c|c|c|c|c|c|c|c|}
\hline \multirow[b]{2}{*}{ Scholastic year } & \multirow{2}{*}{$\begin{array}{l}\text { No. of } \\
\text { school }\end{array}$} & \multicolumn{3}{|c|}{ Students } & \multicolumn{3}{|c|}{ Teachers } \\
\hline & & Male & Female & Total & Male & Female & Total \\
\hline $1952 / 1953$ & 958 & 124804 & 45973 & 170777 & 3039 & 1403 & 4442 \\
\hline $1962 / 1963$ & 1761 & 206348 & 116402 & 322750 & 6500 & 4131 & 10631 \\
\hline $1972 / 1973$ & 1892 & 262269 & 197403 & 459672 & 7893 & 6528 & 14421 \\
\hline $1982 / 1983$ & 2895 & 435170 & 384943 & 820113 & 1317 & 17091 & 31008 \\
\hline $1992 / 1993$ & 3807 & 603282 & 578293 & 1181575 & 21569 & 33689 & 55258 \\
\hline $2000 / 2001$ & 4999 & 730337 & 700509 & 1430846 & 24855 & 43855 & 68720 \\
\hline $2001 / 2002$ & 5137 & 746288 & 717196 & 1463484 & 26803 & 44920 & 71723 \\
\hline $2002 / 2003$ & 5142 & 758023 & 727316 & 1485339 & 28825 & 49155 & 77980 \\
\hline $2003 / 2004$ & 5241 & 768535 & 735815 & 1504350 & 29934 & 51222 & 81156 \\
\hline $2004 / 2005$ & 5366 & 777256 & 745444 & 1522700 & 30514 & 53009 & 83523 \\
\hline
\end{tabular}


J. Social Sci., 5(1): 67-75, 2009

Table 2: Number of school, students, teachers (Teaching stages and social qualitative)

\begin{tabular}{|c|c|c|c|c|c|c|c|}
\hline \multirow[b]{2}{*}{ Teaching stages } & \multirow{2}{*}{$\begin{array}{l}\text { No. of } \\
\text { schools }\end{array}$} & \multicolumn{3}{|c|}{ Students } & \multicolumn{3}{|c|}{ Teachers } \\
\hline & & Female (\%) & Female & Total & Female $(\%)$ & Female & Total \\
\hline Kinder garden & 1228 & 47.07 & 43364 & 92114 & 98.50 & 4459 & 4526 \\
\hline Basic & 2889 & 48.95 & 613943 & 1254131 & 63.81 & 42217 & 66151 \\
\hline Secondary & 1249 & 49.94 & 88137 & 176455 & 49.92 & 6333 & 12846 \\
\hline Total & 5366 & 48.95 & 745444 & 1522700 & 63.46 & 53009 & 83523 \\
\hline
\end{tabular}

a rate $(31.58 \%)$ of the total number of teachers in that year, to reach (53009) teachers for the year (2004/2005), a rate $63.4 \%$ of the total number of teachers.

Table 2 shows the proportion of female students to the total students at each stage of education for the academic year $(2004 / 05)^{[4]}$. At the kindergarten level the total number of male and female students reached (92114) students, while the number of female students was (43364) representing a percentage of $47.07 \%$. Basic level education registered a total students of (1254131) students, out $\mathrm{f}$ which (613943) female students representing a percentage of $48.95 \%$ of the total number of students at this level. For secondary education, the total number of students reached (176455) with female students numbering (88137), a rate $49.94 \%$.In general, the total students enrolled in schools in the Hashemite Kingdom of Jordan, all the different levels of education for the academic year (2004/2005) (1522700) students are (745444) requesting a rate $48.95 \%$ of the total number of students. Table 2 shows the proportion of the female workers to the workers in the field of education in every stage of the education for the academic year (2004/2005). For the kindergarten stage, females constitute an average of $98.5 \%$ of the total educational community at this stage which totals (4526) teachers of both genders due to the ability of the female teacher to deal with this age group and understand their needs better than the male one.

Female teachers also constitute a majority in relation with basic education level, whereby the number is (42217) teachers representing $63.81 \%$ of the total number of (66151) teachers. In general the total number of teachers that are enrolled at Jordan's schools in all levels of education for the academic year (2004/2005) totaled (83523) teachers, out of them (53009). A ratio of female student enrollment in higher education level is considered higher than that of the males A ratio of female student enrollment in higher education level is considered higher than that of the males.

Their percentage in such high studies of different levels (BA, High Diploma and PhD reached 49\%, while females at bachelor degree level in different high institutions (Government and private) recorded 50\%, while the proportion of females in the level of official degree in universities $57.3 \%$. While the percentage did not exceed $31.8 \%$ at the bachelor's level in private universities. In the fields of education courses, humanities, fine arts, architecture, agriculture and natural sciences, the female enrollment figure at Bachelor's level was higher than male enrolment. However, for enrollment in law schools, trade, business management, mathematics, computer, medicine, medical assistance diplomas, science, engineering and veterinary Medicine, male students' enrolment surpassed female enrolment. Female enrolment for higher education in general (diploma, master's and Ph.D.) registered $37 \%$ of the total number of students.

The total number of students enrolled at the bachelor's level in Jordanian universities (government and private ) for the year 2004/2005 was (178619) students, of which (89459) were females, while the number enrolled in graduate studies for the year 2004/2005 was(13937) students of which were females $(4898)^{[5]}$. With regard to literacy rates among adults (age 15 and over), with reference to the proportion of the population of this age group who can read and write, statistics suggests that the proportion of this age group possessing the alphabet skills has increased from $81.3 \%$ for males and $52 \%$ for females in 1979 , jumping in $2002-94.4 \%$ for males and $84.7 \%$ for females.

The qualitative dimension of the development of education in Jordan: We can highlight the qualitative dimension of the development of education in Jordan during the last five decades through educational indicators that reflect continuous efforts aimed at promoting and developing the Jordanian educational system, thus upgrading education and improving the quality and final outcome that reflect positively on the education of girls and boys alike, reaching a level of equal opportunities for both sexes as follows:

The fifties: The move that Jordan took concentrating on elite education to the education for all has made female education a prominent trend that have emerged at this stage with the focus on academic depth, knowledge, scientific excellence, stability of the 
educational ladder after in harmony with the Arab and international educational development of the educational systems. An educational decree No. (20) Was launched for the year in 1955 making student enrolment to schools up to the end of the sixth grade Primary a compulsory matter.

Furthermore, the first step in the area of higher education for the year became law in 1951 by opening a class for teaching training, setting up the first teachers' union in $1952 / 53^{[7]}$.

The sixties: The education act No. (16) for the year 1964 became compulsory opening the door for free education for the first nine years of schooling a compulsory regulation, thus spreading knowledge to rural and urban male and female students.

As the demand for education increased, the Jordanian government was forced to establish more educational institutes and the first national university was set up under the name The University of Jordan was established in 1962 in Amman, the capital.

The seventies: This period was characterized by the pursuit and diversity towards compulsory education in an effort to link it with the needs of the Jordanian community including qualifying teachers by developing their professional skills through effective educational supervision and the introduction of educational innovation on some aspects of the educational learning process. As a result of the increasing number of high school graduates and consistent demand for university education, another university was established in the northern sector of Jordan, namely Yarmulke University in the city of IRBID in 1975.

The eighties: The educational policies in Jordan linked its plans with various plans programs related to economic and social development and focused on teaching education, science, technology, especially computer, along a diversity of educational conferences aiming at the development of the educational process in totality.

During the eighties Jordan passed the provisional law on education No. (27) for the year 1988 and reviewed many regulations and educational laws updating them in view of the structure of education and applied them starting the new school year of 1989/1990, so that basic education period became 10 years.

Instead of nine, making the secondary education two years instead of three. It also witnessed a branching from full comprehensive solid curriculum to applied courses. During this period also, the government continued to establish public universities, the year 1981 Murtha University was the established, the University of Science and Technology of Jordan in 1986, the establishment of the Higher Council of Education which passed its law No. (13) For the year (1980) related to the planning, coordination, policymaking, following up the implementation, coordination and policy-making of the implementation of the higher education sector. It also witnessed the issuance of the unified universities act No. (29) of 1987 to control the pace of university education in various institutions.

The nineties: This stage is considered the most important one as far as education development in Jordan since the issuance of the education act (No. 3) for 1994, incorporating aspects of the most important developmental milestone beginning with the first phase (1988-1995), considered the start-up and planning phase for the provision of infrastructure necessary for the development of key elements of the educational system and the input for stage II (1996-1999) which sought to develop the qualitative dimension of the educational system. Throughout this stage community participation issues of the educational system has been implemented during the national conference of the education of (1999) calling for education as a common national cause.

Jordan records during this period its distinguished role among other neighboring countries, by permitting the establishment of private sector colleges and universities run by private enterprises. The number of private universities climbed to fifteen by the year 2006 .

Decade activities of the new millennium: An assessment of implementation of the efforts of all community institutions took place at the beginning of this decade with regard to education for all, its fields and activities, in addition to preparation of an operational plan for comprehensive and integrated development of various events and elements of the educational process, posed for implementation during the period 2000-2006 of the program of economic and social transformation of the government. It also included the preparation and the implementation of the development projects to the know-how economy and other current matters that the Ministry of Education and the Higher Education establishment sought to develop.

Jordanian women's education and legislation: The Jordanian legislation of various ranks were enacted emphasizing the achievement of the principle of democratic education for all, teaching democracy and education for all regardless of race, language or religious affiliation. 


\section{J. Social Sci., 5(1): 67-75, 2009}

In its article (6), the Jordanian Constitution stipulated as follows:

"Jordanians are equal before the law, no discrimination among them in rights or duties whether they differ on grounds of race, language or religion. The Country shall ensure work opportunities and education within the limits of its possibilities and ensure tranquility and equal opportunities for all its citizens."

Paragraph No. (7) of article (3) of the education act No. (16) of the year 1964 came to confirm in its wording "social justice" and to provide equal opportunities to all citizens of Jordan within the capabilities of individuals themselves.

Paragraph (C) of article No. (3) of the Education Act (No. 3) for 1994 confirmed that "the Jordanians are equal in rights and duties in political, social and economic duties and they are on preferential grounds with the extent of their participation in the community, the feeling of belonging and the need for education. The right of learning is a must and education is a right for all, each according to his own preferences and capabilities. "

The Jordanian National Charter, which was issued in 1990, stipulated that one of the defining features of the Charter and is foundation, stipulated that "Jordanians, men and women are equal before the law, with no discrimination in rights and duties."

Paragraph (D) stipulates on "achieving equality, justice and equal opportunity among all citizens, men and women without discrimination."

Chapter (No. 5) entitled: "Social Domain" stipulates the following on paragraph (5): "Children have the right to obtain the best possible level of care and protection of parents and the government in order to build an independent collaborating personality Jordanian children, without any discrimination between male and female.

Paragraph (6): States that "The women is a partner of a man and an equal in the development of Jordanian society and its development, requiring confirmation of her legal and constitutional right to equality, education, educating others, guidance, training and job opportunities, enabling her to take their rightful role in the building of society and its progress" ${ }^{[8]}$.

The social security act No. (19) For the year 2001 equated between men and women in rights and duties and obligations in general.

Jordanian women and educational efforts to develop them: Jordan's efforts in the area of literacy among women the Ministry of Education spared no effort in the area of adult education, the eradication of illiteracy to improve reading skills of adult citizens and reducing illiteracy problem, since this is a base and the basis for any kind of subsequent education whether academic or professional because it comes as an educational condition to deal with adult education especially women, acting as a remedy of the illiteracy problem, affecting negatively the community, highlighting its impact on the cultural backwardness and difficulty in keeping pace with the rapid changes and unexpected developments nowadays leaving its mark on all aspects of life, particularly on comprehensive development programs.

These efforts have been met with great success scaling down the illiteracy rate in Jordan between various age groups from $(88.0 \%)$ in 1952 to $67.6 \%$ in 1961 and to $19.5 \%$ in 1990 reaching an overall illiteracy ratio of $9.1 \%$ at the end of 2004. The first quarter of the year 2007 recorded illiteracy rate $8.3 \%$, distributed at $4.3 \%$ for males and $12.3 \%$ for females according to Statistics.

Department of Statistics the Ministry of Education initiated comprehensive and implement literacy programs in Jordan to reduce annual illiteracy percentage from a rage of $0.5-1.0 \%$ annually to reach $5.0 \%$ or less by the year 2015 , to be finally eliminated by the year 2020 at the most, at the same time leading the Jordanian educational system to a sustainable education program to bolster literacy habits for those who gained the skills of reading, writing and arithmetic from regressing back to illiteracy.

The number of adult education and literacy centers at the end of the academic year 2006/2007 reached (410) centers, including (34) centers for males and centers (376) for females, with an attendees numbering (5636) of both genders. Out of whom (827) were males and the remaining students (4809) were females.

The Ministry of Education of Jordan has embarked on a two-track methods dealing with this area:

- The system of preventive method: This method represents availing free basic and compulsory education for all members of the community who are of school age. As a result of such policy enrollment of students who are of basic education age, has leapt to more than $95 \%$ for the $2004 / 2005$ academic year

- The system of curative method: This method is divided, in terms of educational level into two phases: The first phase is called the beginners phase lasting a (16) months of the study, alternatively spending two semesters of study whereby the graduate is granted a certificate that 
indicate obtained courses are equivalent to fourth grade level. The second phase, called "follow-up" study with a duration of (16) months of study or two semesters grants the graduate a certificate equivalent to sixth grade level

In conformation with recommendations of Arab and international conferences and to realize the requirements of comprehensive development, a postliteracy curriculum has been put forward in a way that suits students' abilities and preferences and aspirations within the framework of sustainable educational within two tracks of study: academic or vocational. The academic track consists of several programs such as: Evening, home and summer studies. The other program is a follow-up program catered for citizens who have graduated from literacy classes and for those who dropped out of formal education and have reached the age that educational legislations do not permit regular enrolment. Table 3 shows the illiteracy rate in the age groups of (15) years and over for the scholastic years from $(1998-2006)^{[9]}$.

Jordan's efforts in the introduction of reproductive health and gender issues in the curriculum and textbooks: The status of women has turned to the front lines to be presented on the agenda for discussions at international and national population conferences. Many discussions have taken place since the Cairo conference of (1994) and the Beijing conference of (1995), regarding the social gender issues and improvement of the role of women in political, social, economic, health spheres, considering them a paramount importance in achieving sustainable development.

The Jordanian curriculum has highlighted the role of women in Jordanian society through its various institutions, considering them mothers, sisters and Wives on equal footing with men, thus giving them their political and economic roles, explaining that the productive role of women outside their homes is an enrichment to the society and the national income, provided that it does not prejudice their role in honoring their homes and taking full care of their children.

\begin{tabular}{llll}
\multicolumn{5}{l}{ Table 3: Illiteracy $\%($ age $15+)(1998-2006)$} \\
Year & General & & \\
\hline 1998 & illiteracy $(\%)$ & Male $(\%)$ & Female (\%) \\
2000 & 12.7 & 7.1 & 17.9 \\
2002 & 11.0 & 5.7 & 16.5 \\
2004 & 10.3 & 5.4 & 15.2 \\
2005 & 9.1 & 4.5 & 15.2 \\
2006 & 9.0 & 4.8 & 13.3 \\
\hline
\end{tabular}

The Jordanian educational curricula confirm the historical role of women and the role of nurseries and kindergartens in the care of children, leaving the working mother to assume its productive role in the community $^{[10]}$. The educational system also makes great efforts to constantly update the in an effort to keep up with the global continuing changes in science and technology. Hence there exist an addition to the role of women and their positive impact in the community as partners to men in development and contribution.

Jordan's efforts in the field of education and vocational training for females: Recently, Jordan has focused a special attention to the education and the vocational training for females, working continuously to develop this type of direction. Table 4 shows the distribution of students according to the type of vocational education and gender for the year 2004/2005, noting the female turnout for these disciplines $^{[10]}$

The most important prerequisites for increasing the effectiveness of women's role in the educational process within the Jordanian society: In view of what has been raised previously on the development of women's education in Jordan and in spite of the existence of a positive acceleration currently to increase the effectiveness of the role of women and in view of the above conclusions regarding legislations that sided with women and to the efforts that sought to develop their image, we can present a number of proposals aimed at increasing e the effectiveness of women's role in the educational process within the Jordanian society.

As shown in Table 1 the number of female workers in the teaching profession has risen from (1403) teachers for the year (1952/53), the number of students during the past five decades, has doubled several times to reach (1522700) students for the year (2004/2005) indicate that the growing desire of females to work in the service of education compared to males, in addition to the female teachers feeling of stability and tranquility in their work. The proportion of the total female workers in education has risen from 31.58-63.4\% during the last five decades.

As evidenced by the Table 2 there is substantial convergence between the enrollment ratio of male and female students to education in Jordan. These two percentages of $51 \%$ for males and $49 \%$ for females show big closeness of both sexes in Jordan in general and this is a clear indication of the development and care that our society currently offers to educating males and females on similar grounds. In addition to the female teacher's tendency to work in this field more 


\section{J. Social Sci., 5(1): 67-75, 2009}

than male teachers, add to that the closeness of this age group of students with motherhood more than male teachers. Female teacher representing $63.46 \%$ of the total number of teachers at the Ministry of Education in Jordan reflecting the Ministry of Education's intent towards feminization of education at the lower basic stage; while the number of female teachers for the secondary stage education, reached 6333 ) with a rate $49.92 \%$ of the total number of (12846) teachers.

As evidenced by all previous comparisons, the growing demand of women's education in Jordan has been viewed by the increase in their awareness of the importance of education in planning the course of their lives and due to delayed age of marriage for girls paving the way and providing opportunities and miscellaneous educational programs for them.

The indicators generally show the efficiency of educational policies over the last five decades and the effectiveness of official and volunteer efforts in organizing these programs that aim at eliminating and reducing adult illiteracy through education programs directed at eradicating illiteracy through intensive campaigns hunting down pockets that carry such concentration $^{[6]}$.

Because of the Hashemite leadership's keen belief of the need to provide educational opportunities for Jordanians, this trend has been embodied with the educational legislation of different levels starting with the constitution and its passing laws that dealt with the educational matters and related regulations, instructions and applied basics.

Jordan, since an early period of its presence, has recognized the seriousness of illiteracy and its negative effects on various walks of life, by exerting vigorous and intensive efforts to get rid of it in a way that suits the capabilities and aspirations of scholars.

The Ministry of Education further seeks to implement the directions and goals of conferences like Domitian 1990 and Dakar 2000 to achieve education for all and to improve the quality and reduce the illiteracy rate through participation in meetings, workshops, symposia and local Islamic and international conferences.

The increase number of adult education and literacy centers at demonstrate the awareness of Jordanian women of the value and importance of learning, especially the fact that these centers provide vocational training centers in many fields like sewing and agriculture that helped to attract applicants to benefit from the knowledge and skills that can generate reasonable income for themselves and their families.
Table 4: Distribution of students, vocational, stream 2004/2005

\begin{tabular}{lrrr}
\hline & \multicolumn{3}{c}{ Sex } \\
Type of education & Total & Male & Female \\
\hline Sec. vocation & 30949 & 20007 & 10942 \\
Agriculture & 1427 & 1240 & 187 \\
Industry & 9366 & 9273 & 93 \\
Nursing & 2800 & 877 & 1923 \\
Hotels & 1734 & 1734 & 0 \\
Vocational centre & 7087 & 6796 & 290 \\
Home-economic & 8535 & 86 & 8449 \\
\hline
\end{tabular}

It is worth noting that when reviewing the numbers of females Table 4 enrolled in secondary vocational education in various branches, a marked increase is evident in enrollment due to their awareness in the availability of better and greater job opportunities in such specializations.

The Jordanian educational system, with regard to the future of his plans, aspires to provide opportunities for continuous self-learning network through e-learning and distance learning opportunities for all, through computers connected with learning networks.

\section{DISCUSSION}

As shown in Table 1 the number of female workers in the teaching profession has risen from (1403) teachers for the year (1952/53), the number of students during the past five decades, has doubled several times to reach (1522700) students for the year (2004/2005) indicate that the growing desire of females to work in the service of education compared to males, in addition to the female teachers feeling of stability and tranquility in their work. The proportion of the total female workers in education has risen from 31.58-63.4\% during the last five decades.

As evidenced by the Table 2 there is substantial convergence between the enrollment ratio of male and female students to education in Jordan. These two percentages of $51 \%$ for males and $49 \%$ for females show big closeness of both sexes in Jordan in general and this is a clear indication of the development and care that our society currently offers to educating males and females on similar grounds. In addition to the female teacher's tendency to work in this field more than male teachers, add to that the closeness of this age group of students with motherhood more than male teachers. Female teacher representing $63.46 \%$ of the total number of teachers at the Ministry of Education in Jordan reflecting the Ministry of Education's intent towards feminization of education at the lower basic stage; while the number of female teachers for the secondary stage education, reached 6333) with a rate $49.92 \%$ of the total number of (12846) teachers. 
As evidenced by all previous comparisons, the growing demand of women's education in Jordan has been viewed by the increase in their awareness of the importance of education in planning the course of their lives and due to delayed age of marriage for girls paving the way and providing opportunities and miscellaneous educational programs for them.

The indicators generally show the efficiency of educational policies over the last five decades and the effectiveness of official and volunteer efforts in organizing these programs that aim at eliminating and reducing adult illiteracy through education programs directed at eradicating illiteracy through intensive campaigns hunting down pockets that carry such concentration $^{[6]}$.

Because of the Hashemite leadership's keen belief of the need to provide educational opportunities for Jordanians, this trend has been embodied with the educational legislation of different levels starting with the constitution and its passing laws that dealt with the educational matters and related regulations, instructions and applied basics.

Jordan, since an early period of its presence, has recognized the seriousness of illiteracy and its negative effects on various walks of life, by exerting vigorous and intensive efforts to get rid of it in a way that suits the capabilities and aspirations of scholars.

The Ministry of Education further seeks to implement the directions and goals of conferences like Domitian 1990 and Dakar 2000 to achieve education for all and to improve the quality and reduce the illiteracy rate through participation in meetings, workshops, symposia and local Islamic and international conferences.

The increase number of adult education and literacy centers at demonstrate the awareness of Jordanian women of the value and importance of learning, especially the fact that these centers provide vocational training centers in many fields like sewing and agriculture that helped to attract applicants to benefit from the knowledge and skills that can generate reasonable income for themselves and their families.

It is worth noting that when reviewing the numbers of females Table 4 enrolled in secondary vocational education in various branches, a marked increase is evident in enrollment due to their awareness in the availability of better and greater job opportunities in such specializations.

The Jordanian educational system, with regard to the future of his plans, aspires to provide opportunities for continuous self-learning network through e-learning and distance learning opportunities for all, through computers connected with learning networks.

\section{CONCLUSION}

The educational system in Jordan focused its attention on women seeking to make a quantitative and qualitative aspects quantum leap that matches or even surpasses the development that had taken place for male education. Teaching women plays a key role in the process of economic and social development, with all its dimensions in Jordan for the purpose of achieving active and interactive coexistence for the males and females of Jordan in a community of twenty first century, in a vision that realizes active contribution for men and women together, hand in hand in economic and social development with their full creative energies noting that they are the most expensive and valuable assets in the country's knowledge banks.

Recommendation: It should be decided to include these concepts in textbooks, according to major fields, the most prominent are:

- The area of population dynamics, which includes the following topics: Natural population increase, family planning, direct causes and average numbers of mortality, population growth and health

- The area of family and society, which includes the following topics: The components of the family, duties and rights of family members, relations and rights of parents \& children, the duties and rules of behavior, nutrition and health

- Supporting student women and those working towards self-development facing difficulties and challenges that impede progress, in different educational institutions through holding of workshops aimed at creating society awareness on the importance of women's multiple roles

- Developing positive trends in women's employment and them active participation in society

- Ensuring equal opportunities for women in striving for education and services giving them equal opportunities in employment

- Activating the regulations and instructions contained in the legislation and laws, which refers to equality and equal opportunities between both sexes in order to achieve justice for women in educational institutions

- Developing a "culture of community" towards vocational and technical education for women in proportion to the scientific and technical developments in a way that caters to the needs of the Jordanian society 
- Expanding the quantitative and qualitative aspects in women's education programs thus improving \& diversifying facilities available to females in the areas of basic and higher education spheres

- Developing the image of women in the educational curriculum as a housewife, teacher, nurse, writer, philosopher, with their participation in various social and religious activities

- Integrating formal and informal education in the context of the philosophy of education through opening of channels, extending bridges between them without restrictions and activation of popular participation in order to take a role in the fight of illiteracy

\section{REFERENCES}

1. Mou'taman, M.R., 2005. Women and Higher Education in Jordan. 4th End., Amman, Jordan, ISBN: 743-1-1119-8, pp: 56.

2. The United Nations, 2000. Human Development Statistics. 1st End., pp: 89.

3. Ministry of Higher Education and Scientific Research, 2005. Annual Statistics on Higher Education in Jordan for the year 2004/2005. 1st End., Amman, Jordan, ISBN: 306-67-9987-21, pp: 55-90.
4. Ministry of Education, 2005. Annual Educational Statistics Bulletins from 1952-2005. 1st End., Amman, Jordan, ISBN: 154-52776-6190, pp: 90-127.

5. Ministry of Education, 2005. Educational Statistics for the Academic Year 2004/2005. 1st Edn., Educational Planning Department, Amman, Jordan, ISBN: 10-0441-287492, pp: 34-56.

6. Mou'taman, M., 2004. Jordanian Women and Education. 2nd End., Amman, Jordan, ISBN: 1055577-61-309.

7. Mou'taman, M.R., 1993. The Education of Women in the Era of King Hussein-Major Landmarks. 3rd End., Amman, Jordan, ISNB: 8-8547-7712-33, pp: 77-89.

8. Jordanian National Charter, 1990. The Jordanian National Charter. 1st Edn., Amman, Jordan, ISBN: 4445-9879-786, pp: 67-89.

9. Musa, A.S., 2001. The Jordanian Experience in the Integration of the Concepts of Reproductive Health and Gender Issues from the Perspective of Islamic Social Programs in Pre-University Education. 2nd Edn., Amman, Jordan, ISBN: 7-088-755-4321, pp: 90-134.

10. The Ministry of Education, 2006. Legislation on Compulsory Education in Jordan. 3rd Edn., Aman, Jordan, ISBN: 509-5612-7753, pp: 98-150. 